\title{
WORKPLACE SPIRITUALITY AND JOB CRAFTING: EFFORTS TO ELIMINATE THE IMPACT OF WORK OVERLOAD
}

\author{
A. Khoirul Anam¹, Anna Widiastuti², Fathur Rofiq ${ }^{3}$ \\ 1,2 Postgraduate student, Faculty of Economics, Universitas Islam Sultan Agung, Semarang, Indonesia \\ ${ }^{3}$ Faculty of Economics and Business, Universitas Islam Nahdlatul Ulama, Jepara, Indonesia \\ e-mails: ${ }^{1}$ anam@unisnu.ac.id; ${ }^{2}$ annafeb2013@unisnu.ac.id; ${ }^{3}$ fathurvictor@gmail.com \\ Received May 5, 2020; accepted June 30, 2020; published July 1, 2020.
}

\begin{abstract}
Objective: This study discusses the importance of job crafting and workplace spirituality on the impact of role overload, which in turn leads to increase job performance. There is a limited previous research on job crafting and workplace spirituality, especially in the microfinance institutions. Research Design \& Methods: Our research seeks to gain further understanding of the overall work overload occurrence, so we choose samples from microfinance institutions that can be expected to show excessive roles because of character of their work that is frequently in high pressure. Data collected from 119 questionnaires were analyzed using PLS-SEM with SMART-PLS software. Findings: The results showed that employees experienced work overload of both quantitative overload (feeling of any more work than the available time allocation) and qualitative overload (sense that the work requires skills, abilities and knowledge beyond the capacity of the individual), yet failed to show the role of workplace spirituality as a moderating variable. Implications \& Recommendations: Future research can be carried out at larger institutions or industries and a larger number of samples for the sake of generalization and work overload occurence related to certain industrial situations. Contribution \& Value Added: Our main contributions lie on the proposition that job crafting and workplace spirituality play a role in eliminating the impact of work overload. This study reinforces role evidence of job crafting and workplace spirituality on the impact of role overload.
\end{abstract}

Keywords: workplace spirituality, job crafting, role overload, job performance, microfinance institution.

JEL codes: G21, J24, O15

Article type: research paper

\section{INTRODUCTION}

Role overload is not a new case, but it has attracted many researchers to examine it. This is the root cause of many problems and threats to employees in an organization. It was found in this disruptive era to be one of the most serious and rapidly growing phenomena in the organization, and a cause of low productivity (Malik et al., 2013), with the result that it needs a creative-effort to improve employee productivity by facilitating job crafting and creating a culture of spirituality, which is expected to eliminate the impact of role overload.

Role overload is related to an individual's inability to resolve excessive work demands. The presence of a larger job makes the employees experience an overload that causes them to use their time to accommodate the work-demands (Duxbury, Higgins, \& Network, 2001). Role overload as a form of personal role conflict shows the perception that the existing-roles demands are greater than the capabilities and available resources (Jones, Chonko, Rangarajan, \& Roberts, 2007). One of the most studied indicators of workload is a work-stress, determination of job-specifications, and changes in work patterns, however slightly-known of the factors that influence role overloads such as workplace 
spirituality (Altaf \& Awan, 2011) and job crafting (Solberg \& Wong, 2016). Previous research also revealed that excess role as a negative predictor of employee productivity (Campion, Mumford, Morgeson, \& Nahrgang, 2005). But in another study by (Malik \& Usman, 2011), found that there is a positive relationship between excess roles and productivity.

In recent years, the research has directed attention to workplace spirituality and its impact on employee performance (Duchon \& Plowman, 2005; Moon, Youn, Hur, \& Kim, 2018; Olivia, Ardian, \& Mutaminah, 2014); spirituality and organizational management (Mitroff \& Denton, 1999); spirituality and profitability (Krishnakumar \& Neck, 2002); leadership and spirituality (Fry, 2003); workplace spirituality and the impact on employee involvement (Kolodinsky, Giacalone, \& Jurkiewicz, 2008; Pawar, 2009; Saks, 2011). Although the debates still emerge regarding the definition of spirituality which is widely accepted (Altaf \& Awan, 2011; Fourie, 2014; Karakas, 2010; Kinjerski \& Skrypnek, 2004), all of the studies acknowledged that an individual functions a spiritual being, there is an opportunity to carry out spirituality in the workplace and the development of the concept of the spiritual work environment.

The spirituality in the workplace emphasizes the needs of employees and achieves better productivity because appreciated employees tend to show better performance. The better quality of spirituality in the work environment, the better working conditions, and job satisfaction, which ultimately results in improved performance, job involvement, higher profits, organizational commitment, and widespread success.

Job crafting is an approach that employees can use to improve their satisfaction and performance, but relatively unexplored in the literature (Slemp \& Vella-Brodrick, 2013; Wrzesniewski \& Dutton, 2001) and several studies that have been done before are theoretical (Berg, Grant, \& Johnson, 2010; Berg, Wrzesniewski, \& Dutton, 2010; Fried, Grant, Levi, Hadani, \& Slowik, 2007; Lyons, 2008; Wrzesniewski \& Dutton, 2001), so there is still an important need to empirically analyze the relationship between job crafting and other influential variables. The results of previous studies also show differences in results where, there is no significant relationship between craftwork and performance (Martinez \& Solem, 2019), in contrast to (Tims, Bakker, \& Derks, 2012) job crafting is positively correlated with performance assessed by colleagues.

Microfinance Institutions (MFIs) are financial institutions that have a role as providers of financial services for SMEs and as an alternative to assisting business development and community empowerment (Anam \& Nahar, 2015). The strength of MFI depends on the quality of human resources, therefore, the employee must have sufficient skills. MFIs are usual-managed ones with inadequate structural composition, but the load demands and risks-facing the same financial institutions generally. Having known the made-observations, many of the MFIs have multiple structures (for example, marketing financing which simultaneously doubles as marketing funding, from online service officer doubles as a teller, customer service is concurrent as accounting). This triggers a work overload that must be borne by employees because they have a dual role in workduties. Role overload has been found to have a detrimental effect on the welfare of employees. When employees become more stressed, physical and mental health decreases, lower organizational commitment, and higher absenteeism will happen (Duxbury et al., 2001).

Another problem relates to the organizational concern for employees in carrying out the work is that the lack of awareness would make employees less creative and less productive. Therefore, a creative effort is required to increase employee productivity in an organization, among facilitating job crafting and creating a culture of workplace spirituality, which is expected to eliminate the impact of role overload.

This research aims to develop a model of workplace spirituality and job crafting as an attempt to eliminate the impact of excessive workload which is believed to be able to improve the performance of employees. 


\section{LITERATURE REVIEW}

\section{Role Overload}

It is generally accepted that work stress as role overload can reduce a person's ability to control his environment, thus affecting the ability of individuals to work efficiently. However, the literature provides little empirical support about the performance of work stress (Jones et al., 2007), although the reasonable explanation for the two variables have been described (Bakker, Demerouti, \& Euwema, 2005), and the concluding reason to continue has been done to examine the relationship of work stress on performance.

In the literature, differences between the dimensions of quantitative role overload and qualitative role overload have been developed. Quantitative role overload is a feeling of more work than the available time allocation (Beehr, Walsh, \& Thomas, 1976), also tend to experience qualitative role overload feeling that the job requires skills, abilities, and knowledge beyond the capacity of the individual (Pienaar, Mostert, \& Sieberhagen, 2007). However, the two dimensions of role overload are related to individual and professional characteristics and abilities, and the nature of the work itself (Pienaar et al., 2007). The results of previous studies showed that role overload was a negative predictor of employee productivity (Astuti \& Palupiningdyah, 2018; Campion et al., 2005; Iroegbu, 2014)

H1: Work overload has negative effect on Job performance.

\section{Job Crafting}

The previous research has emphasized that job crafting can produce better communication, more efficient collaboration, and higher productivity (Leana, 2009). Job crafting is generally carried out as a proactive means to deal with challenging job demands (Daniels, Beesley, Wimalasiri, \& Cheyne, 2013; Petrou, Demerouti, Peeters, Schaufeli, \& Hetland, 2012). The existing literature shows that employees are not allowed to do job crafting in situations of role overload without adequate facilitation, as it significantly threatens the ability of employees to work effectively, generallyclassified as obstructing job requests (Crawford, LePine, \& Rich, 2010; LePine, Podsakoff, \& LePine, 2005; Podsakoff, Lepine, \& Lepine, 2007). The findings of the meta-analytic study support that the demands of work that inhibits including role overload are negatively related to performance (LePine et al., 2005) and other important results, including work involvement (Crawford et al., 2010), worksatisfied, and organizational commitment (Podsakoff et al., 2007), by increasing tension and decreasing motivation (LePine et al., 2005). Research Tims et al. (2012) revealed the results that job crafting is positively correlated to performance.

H2: Work overload has negative effect on Job crafting

H3: Job crafting has positive effect on Job performance

H4: Job crafting mediates the influence between work overload to job crafting

\section{Workplace Spirituality}

Spirituality in the literature is described as something that leads to personal satisfaction in people's life, which in turn results in the realization that people's lives has meanings and purposes. A study conducted on workplace spirituality has provided input regarding the theme of spirituality in the workplace (Marques, Dhiman, \& King, 2015) including ethics, trust, trust in God, respect, understanding, openness, honesty, self-motivation, encouraging creativity, sharing with others, kindness, team orientation, several organizational barriers, a sense of peace and harmony, a pleasant workplace, interconnectedness, encouraged diversity, and acceptance.

Several other studies have been conducted by different researchers about spirituality, each identifying dimensions of spirituality and spirituality in different workplaces. Several identified factors have caused the emergence of spirituality such as fear of something unknown or known, for example, losing a job or feeling lonely and unable to achieve satisfaction with life or work-done and so on. 
Excessive work does not seem to be widely studied compared to workplace spirituality and job satisfaction (Altaf \& Awan, 2011). With the increase in workload, working hours, and supervision pressure to achieve competitiveness and company goals, excess work hours are of an important concern (Altaf \& Awan, 2011). Several studies have been carried out to reduce the effect of excess work, but little is known about the influence of workplace spirituality in organizations to reduce the impact of excessive workload.

Quantitative overload is found to be a source of stress that had been caused by time pressure and work difficulties (Mazloum, Kumashiro, Izumi, \& Higuchi, 2008). The cause of the low level of job satisfaction is fatigue, which shows a negative relationship with the excessive caused by fatigue conditions in the workplace.

People discern work as a source of salary. In the current situation, people are considering having good working conditions or working alone as good and ethical members of the organization, have attractive jobs, earn income, have peers who support, and help the community (Mitroff \& Denton, 1999). Meaning, purpose, and satisfaction are three important components of spirituality. These factors further become a performance motivator and a positive attitude towards the organization. Spirituality is be positively related to job satisfaction (Davis, Kerr, \& Kurpius, 2003) and positive work attitude (Neck \& Milliman, 1994), which in turn will improve performance. High religiosity will increase the integrity of the person, so it has the resilience to face the pressures of work (Suprasto et al., 2017).

H5a: Workplace spirituality has positive effect on Job performance.

H5b: Workplace spirituality moderates effect between Work overload to Job Performance.

H6a: Workplace spirituality moderates effect between Role overload to Job crafting.

H6b: Workplace spirituality has positive effect on Job crafting.

\section{METHODS}

The data was collected by using a structured questionnaire, while the research carried out is 'explanatory research', by emphasizing the relationship between the variables through hypothesis testing, where the brief contains the description, but the focus is on the relationship between variables (Widodo, 2014). The variable in question includes: work overload (WO), workplace spirituality (WS), job crafting (JC) and job performance (JP). The population is limited to employees working in Microfinance Institutions (MFIs). The sample of employees chosen is all employees who are members of the cooperative association of Artha Group and Mitra Muamalah. The two cooperative associations were chosen because they represented a different culture from the existence of cooperatives in the Jepara Regency, a region in Central Java Province, Indonesia.

Work overload is measured through 8 indicators developed by Creary \& Gordon (2016); Triplett, Mullings, \& Scarborough (1996); and Wang, Liu, \& Liu (2018). Encompassing quantitative overload is a feeling of too many tasks to be accomplished compared to the available time allocation, and qualitative overload refers to the work that must be completed is too difficult also compared to the skills and abilities possessed. Workplace spirituality is measured using 8 indicators developed by (Altaf \& Awan, 2011) to justify, honesty, moral values, needs, employee development, respect, support, and encouragement to employees. Job crafting is measured using 4 indicators developed by Berg, Grant, et al. (2010); Leana (2009); and Moon et al. (2018) by using new approaches, change of work procedures, change of the way to do the work, and rearrangement of workplace equipment. Job performance measured using 4 indicators developed by (Moon et al., 2018); (Sartori, Costantini, Ceschi, \& Scalco, 2017), completing assigned tasks, performing tasks as expected, and fulfilling formal performance requirements and mandatory aspects of work.

Due to the small sample size, the data were analyzed using PLS-SEM with SMART-PLS software. PLS-SEM have been selected because of its advantages compared to the covariance-based modeling, and to produce strong results for the small sample size (Abdillah \& Jogiyanto, 2015). 131 questionnaires were distributed and 119 questionnaires were returned (91\%). From the results of statistical analysis confirms that the measurement model is reliable and valid (Table 1). There are 4 indicators with a loading score of less than 0.7. According to (Abdillah \& Jogiyanto, 2015), 
convergent validity for social science can be less than 0.7 . If the convergent validity between $0.4-0.7$ should not be removed along with the score EVA and communality of these indicators $>0.5$.

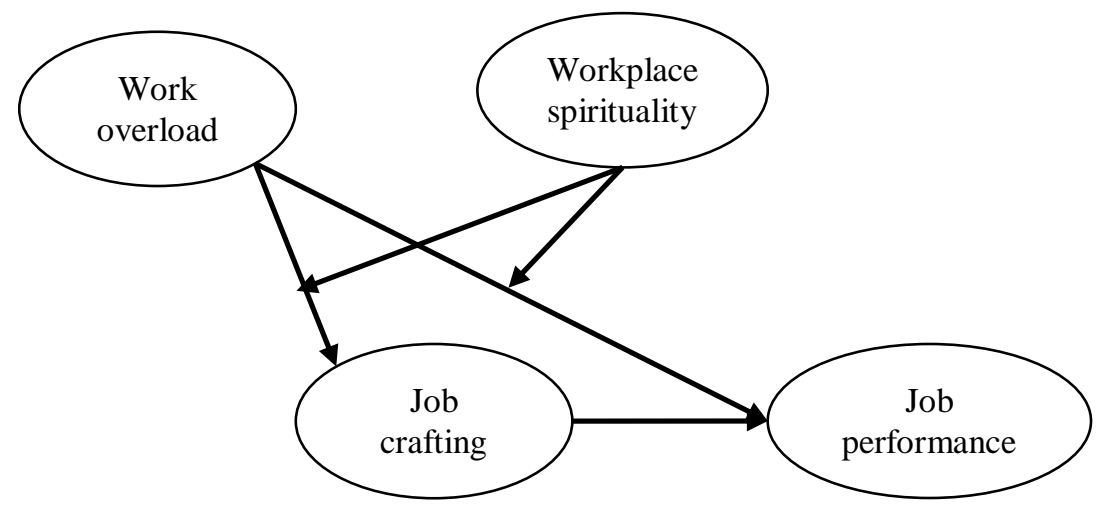

Figure 1. Empirical research model

\section{FINDING}

Based on the results of the statistical analysis of the measurement model, it was concluded that the indicators are by the specified constructs. Convergent validity of the measurement model in loading factor value based on indicators that measure the construct. This research has 4 constructs with a number of indicators between 4 and 8 indicators and uses a numerical scale of 1 to 10 , with loading score parameters in the research model rule of thumbs $>0.7$, score AVE $>0.5$ and communality $>0.5$. In the construct of job crafting and job performance, all indicators have a loading factor above 0.7 , AVE 0.5 dan communality $>0.5$. While the work overload has 2 indicators with a loading factor of less than 0.7 (0.645 and 0.595); workplace spirituality has 2 indicators with a loading factor of less than 0.7 (0.674 and 0.603).

Table 1. Summary of Measurement Models

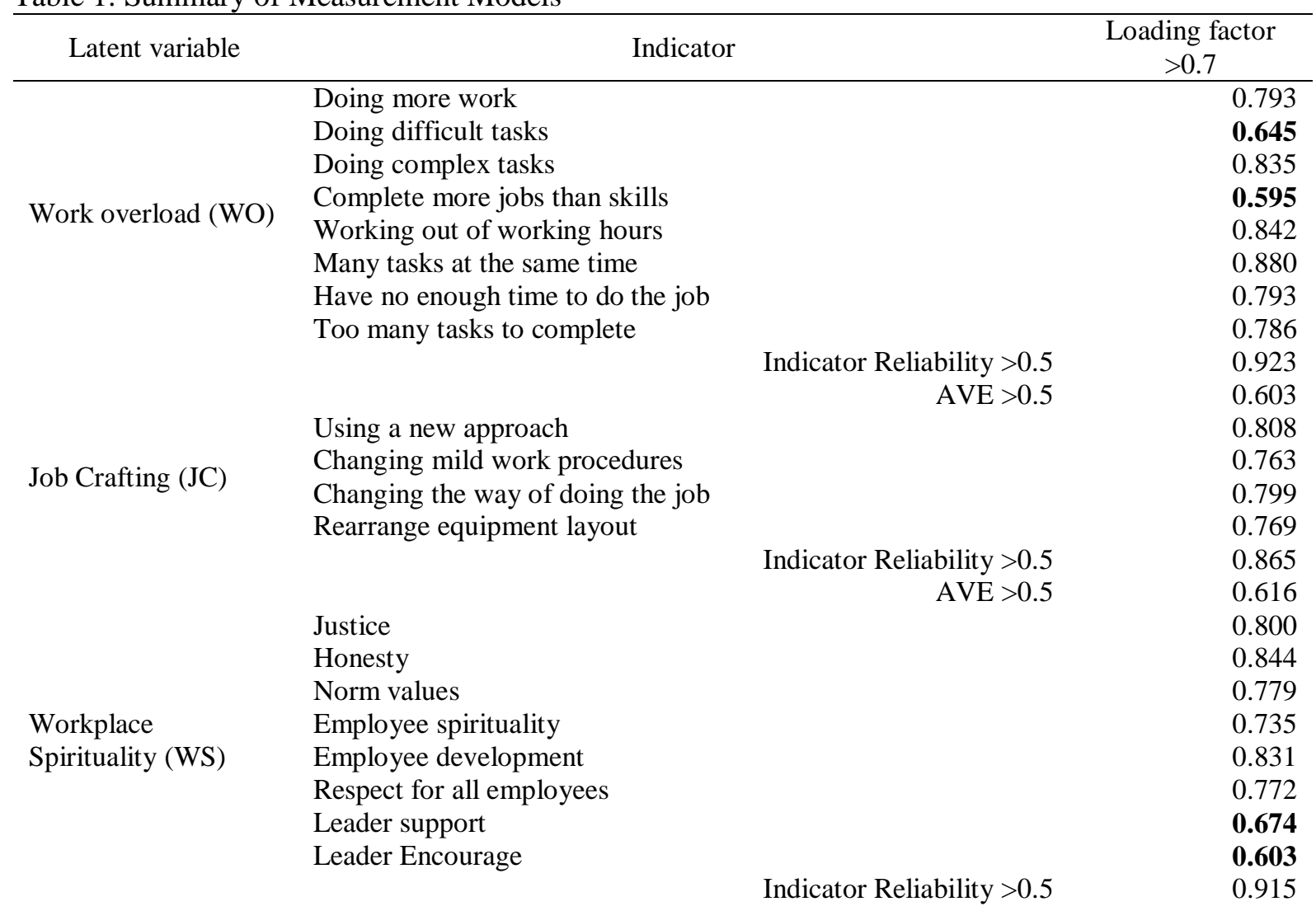




\begin{tabular}{clrr}
\hline Latent variable & \multicolumn{1}{c}{ Indicator } & \multicolumn{2}{c}{$\begin{array}{c}\text { Loading factor } \\
>0.7\end{array}$} \\
\hline & & AVE $>0.5$ & 0.575 \\
& Complete tasks well & 0.858 \\
Job Performance $(\mathrm{JP})$ & Complete tasks according to expertise requirements & 0.833 \\
& Fulfill formal performance requirements & 0.854 \\
& Fulfill the aspects of mandatory work & 0.850 \\
& & Indicator Reliability $>0.5$ & 0.912 \\
& & AVE $>0.5$ & 0.720 \\
\hline
\end{tabular}

Source: SEM Analysis

131 questionnaires were distributed, 119 questionnaires were returned (91\%). After assessing the completeness and removing duplication, 115 questionnaires were declared to be eligible for testing. The demographics of the respondents are observed in Table 2.

Table 2. Demography of the Respondents

\begin{tabular}{|c|c|c|}
\hline Characteristics & Items & Percentage \\
\hline \multirow[t]{2}{*}{ Gender } & Male & $43 \%$ \\
\hline & Female & $57 \%$ \\
\hline \multirow[t]{3}{*}{ Age } & $17-25$ & $46 \%$ \\
\hline & $26-35$ & $44 \%$ \\
\hline & $36-45$ & $10 \%$ \\
\hline \multirow[t]{2}{*}{ Education level } & High School & $32 \%$ \\
\hline & Bachelor Degree & $68 \%$ \\
\hline \multirow[t]{3}{*}{ Working period } & $1-2$ & $45 \%$ \\
\hline & $3-4$ & $20 \%$ \\
\hline & $5-6$ & $35 \%$ \\
\hline \multirow[t]{4}{*}{ Position } & Teller, CSO, Accountant & $23 \%$ \\
\hline & Admin, Internal Control Unit & $9 \%$ \\
\hline & Manager & $14 \%$ \\
\hline & Marketing & $54 \%$ \\
\hline
\end{tabular}

Statistical analysis to evaluate structural models shows that R2 of job performance is 0.492 and job crafting is 0.541. According to (Hair, Black, Babin, \& Anderson, 2014), stated that in scientific research, the value of R2 $0.75,0.5$, or 0.25 for endogenous variables can be described as substantial, moderate, or weak. Based on R2 endogenous variables in the model can explain moderately the exogenous variables.

Table 3. Path Coefficient

\begin{tabular}{lrrrrr}
\hline & $\begin{array}{c}\text { Original Sample } \\
(\mathrm{O})\end{array}$ & $\begin{array}{c}\text { Sample Mean } \\
(\mathrm{M})\end{array}$ & $\begin{array}{c}\text { Standard } \\
\text { Deviation } \\
(\text { STDEV })\end{array}$ & $\begin{array}{c}\text { T Statistics } \\
(\mid \mathrm{O} / \text { STDEV } \mid)\end{array}$ & P Values \\
\hline WO -> JP & -0.127 & -0.125 & 0.068 & 1.874 & 0.031 \\
WO -> JC & -0.421 & -0.424 & 0.060 & 6.964 & 0.000 \\
QnO -> JP & -0.116 & -0.097 & 0.112 & 1.034 & 0.151 \\
QnO -> JC & -0.145 & -0.147 & 0.122 & 1.181 & 0.119 \\
Q1O -> JP & -0.010 & -0.028 & 0.128 & 0.076 & 0.470 \\
Q1O -> JC & -0.310 & -0.303 & 0.120 & 2.576 & 0.005 \\
JC -> JP & 0.264 & 0.263 & 0.100 & 2.637 & 0.004 \\
WS -> JP & 0.413 & 0.420 & 0.105 & 3.947 & 0.000 \\
WS -> JC & 0.529 & 0.530 & 0.059 & 8.900 & 0.000 \\
ME1 -> JC & -0.023 & -0.028 & 0.049 & 0.470 & 0.319 \\
ME2 -> JP & -0.056 & -0.048 & 0.065 & 0.865 & 0.194 \\
\hline S
\end{tabular}

Source: SEM Analysis

*ME1, ME2: Moderating Effect 1 dan 2

Work overload significantly affect to job performance (coefficient $=-0.127, p=0.031$ ) and job crafting (coefficient $=-0.421, \mathrm{p}=0.000$ ), and job crafting significantly affect to job performance (coefficient $=0.265, \mathrm{p}=0.004$ ). So based on a statistical test results support the hypothesis 1,2 and 3 . 
The work spirituality significantly affects the job performance (coefficient $=0.413, p=0.000$ ) and job crafting (coefficient $=0.529, \mathrm{p}=0.000$ ), but the moderating effect of both moderation on job crafting and job performance shows that the T-statistic moderations $<1.96$ means that workplace spirituality does not moderate the effect of work overload on job performance and work overload on job crafting. Having the finding that is based on the results of statistical tests supporting hypotheses H5a and H6a, the moderating effect for hypotheses H5b and H6b are not supported.

Then the hypothesis 4 proposed that job crafting mediates the relationship between work overload and job performance. The results of the research show that work overload $\rightarrow$ job crafting $($ T-Statistic $=$ $6.964)$ and job crafting $->$ job performance $($ T-statistic $=2.637)$, the value of T-statistic $>1.96$, means job crafting is fully-mediating affect work overload to job performance. Therefore, hypothesis 4 is aimed at mediating the effects supported.

\section{DISCUSSION}

Explanatory research-based research conducted on MFIs is related to role overload. Research on role overload in MFIs is rarely done. The unique characteristics of MFIs, as in the form of institutions, usually have a simple structure, serving the community, especially in the micro, small and medium enterprises sector, in the community and productive business sectors that are not served by banks because they are considered less bankable. The object of the MFI's service with these characteristics and its structure is quite simple, making the MFIs faced with a high level of risk. This allows MFIs in operational activities faced with the pressure of a very challenging job. Also, employees are demanded high performance, multiple workloads, and pressure on achieving performance targets and completing work.

Role overload refers to the feeling of excess workload, due to the large amount of work that must be done while the available time allocation is limited (quantitative overload), and demands for difficult jobs are not within the capacity of employees (qualitative overload). The results showed that job overload hurt job performance in the MFIs that were the object of research. This result is by Campion et al. (2005) that role overload may function as a negative predictor of employee productivity.

Based on the results of the observation, this indicates that quantitative overload is indicated by the number of main tasks (the most dominant factor) and additional tasks that must be completed by the employees. Also, employees are often asked by supervisors to back up work colleagues who do not meet performance targets. The limited number of employees, simple structure, and demands for performance targets have explained. Respondents also stated that many tasks could not be resolved on their own, but needed teamwork involvement. Numbers of assignments whose work instructions are unclear are not given sufficient technical guidance and explanations and many tasks that require a lot of effort, strategies, and special skills, but not many education and training facilities are provided to employees. Whereas quantitative overload is indicated by the fact of frequent having to arrive early and go home later, to complete work, and to use breaks to accomplish the work. Unclear work procedures are influential to the priority of work and communication (teamwork) that do not run well.

Employees who are faced with harsh working conditions can lead to poor performance and lack of satisfaction and work performance as expected and desire by the company (Altaf \& Awan, 2011). In addition to challenges from the environment, competition, customer orientation, competitive services, and changing technology, making the business more complicated and making employees feel besieged. Therefore, a solution is needed that might not only help overcome the problems suffered by employees because of work overload, but also something that can help them increase productivity and cope with the symptoms work overload. (Czaplewski, Ferguson, \& Milliman, 2003) also suggests ensuring that employees have a clear direction that will make them more creative.

This research develops the factors that affect role overloads such as job crafting (Solberg \& Wong, 2016) and a spirituality workplace (Altaf \& Awan, 2011). Job crafting has not been explored in the relative literature (Slemp \& Vella-Brodrick, 2013; Wrzesniewski \& Dutton, 2001) and several previous studies are theoretical (Berg, Grant, et al., 2010; Berg, Wrzesniewski, et al., 2010; Fried et al., 2007; Lyons, 2008; Wrzesniewski \& Dutton, 2001). This study temporarily observes the mediating

JMER, 2020, 01(1), 13-23 
effects of job crafting to work overload toward job performance, show results that job crafting positively affects job performance, mediate the influence of work overload toward job performance. Job crafting is generally carried out as a proactive means to deal with challenging job demands (Daniels et al., 2013; Petrou et al., 2012). Based on the results of job crafting observations shown by employees in the form of changing work patterns from the usual, such as simplifying work procedures so that it becomes easier, faster, better than before, making notes/agenda of priority issues and work completion checks. Other activities carried out by employees such as arranging documents, providing labeling of documents to make them more traceable are the most dominant factors of crafting behavior by employees.

Workplace spirituality can be one of the factors that can be used to overcome the impact of work overload (Altaf \& Awan, 2011). Providing work spirituality to employees also helps in better interaction and communication. Improved-communication among employees can build honesty and trust between them. Spirituality is positively related to job satisfaction (Davis et al., 2003) and positive work attitude (Neck \& Milliman, 1994), in turn, to improve performance. The achieved result is that the spirituality of the workplace does not moderate the relationship between the work overload and job performance. Perhaps this finding can be explained from the statements of respondents who stated that there was a perception of injustice, debates related to work comfort standards, lack of openness of management, programs and patterns of employee development that were not optimal, lack of appreciation from management and employees who had to solve their work difficulties. Another possible reason is that the sample size is only 115 people, which could also be caused by the moderating effect that does not reach significance.

\section{CONCLUSION}

The results showed that employees experienced work overload of both quantitative overload (feeling of any more work than the available time allocation) and qualitative overload (a sense that the work requires skills, abilities, knowledge beyond the capacity of the individual). Then the differences between quantitative and qualitative dimensions are more theoretical, yet both dimensions are required to improve our understanding of the role overload dimensions. The purpose of a high volume of work (quantitative) or a very complex (qualitative) work assignment can be considered rather inconsistent. However, having an interesting finding when testing separately between the two dimensions, the results are not significant (Table 3). This might indicate a problem with dimensional instability, due to lack of consistency (Pienaar et al., 2007), or by the characteristics and objectives of the job demands.

Our research seeks to gain further understanding of the overall work overload occurrence so that we chose samples from microfinance institutions that were expected to show excessive roles since the nature of their work is often in-high pressure. Future research can be carried out at larger institutions or industries and a larger number of samples for the sake of generalization and work overload occurrence related to certain industrial situations (Jones et al., 2007). The difference between the advantages of qualitative and quantitative roles is needed by having an intention that we may comprehend our understanding on the excessive role constructs generally.

Our main contributions lie to the proposition that job crafting and workplace spirituality play a role in eliminating the impact of work overload. Our research also identifies employee perceptions relating to the variables under study through open statements embedded in the questionnaire, to obtaining a clearer description relating to research problems, as support for considering the dimensions of the variables studied, as well as previous research related to factors that influence role overloads such as job crafting (Solberg \& Wong, 2016) and workplace spirituality (Altaf \& Awan, 2011).

These results can be used by managers of microfinance institutions in a variety of ways, job design is created to encourage creativity and uncover the potential of employees. Invite the active participation of employees to make changes in patterns, work atmosphere, and improvisation on the implementation of work. The results of the study indicate that workplace spirituality influences workload needs to develop respect for fellow employees, employee development, appreciation, provide support and encouragement to employees. Many studies reveal that the demands of work complexity. 


\section{REFERENCES}

Abdillah, W., \& Jogiyanto, H. (2015). Partial Least Square (PLS)-Alternatif Structural Equation Modeling (SEM) dalam Penelitian Bisnis (1st ed.; D. Prabantini, ed.). Yogyakarta: Peneribit ANDI Yogyakarta.

Altaf, A., \& Awan, M. A. (2011). Moderating Affect of Workplace Spirituality on the Relationship of Job Overload and Job Satisfaction. Journal of Business Ethics, 104(1), 93-99. https://doi.org/10.1007/s10551-011-0891-0

Anam, A. K., \& Nahar, A. (2015). Identifikasi Model Pembiayaan Usaha Kecil dan Menengah Oleh Lembaga Keuangan Mikro Di Kabupaten Jepara. Buletin Bisnis \& Manajemen, 1(2), 46-53.

Astuti, N., \& Palupiningdyah. (2018). the Effect of Work Overload on Job Performance With Emotional Exhaustion As Mediating Variable ( Study At Employee. Issn 2252-6552, 7(2).

Bakker, A. B., Demerouti, E., \& Euwema, M. C. (2005). Job Resources Buffer The Impact of Job Demands on Burnout. Journal of Occupational Health Psychology, 10(2), 170-180. https://doi.org/10.1037/1076-8998.10.2.170

Beehr, T. A., Walsh, J. T., \& Thomas, D. (1976). Relationship of Stress to Individually and Organizationally Valued States : Higher Order Needs as a Moderator. 61(1), 41-47.

Berg, J. M., Grant, A. M., \& Johnson, V. (2010). When Callings Are Calling: Crafting Work and Leisure in Pursuit of Unanswered Occupational Callings. Organization Science. https://doi.org/10.1287/orsc.1090.0497

Berg, J. M., Wrzesniewski, A., \& Dutton, J. E. (2010). Perceiving and Responding to Challenges in Job Crafting at Different Ranks: When Proactivity Requires Adaptivity. Journal of Organizational Behavior. https://doi.org/10.1002/job.645

Campion, M. A., Mumford, T. V, Morgeson, F. P., \& Nahrgang, J. D. (2005). Work Redesign: Eight Obstacles and Opportunities. Human Resource Management, 44(4), 367-390. https://doi.org/10.1002/hrm.20080

Crawford, E. R., LePine, J. A., \& Rich, B. L. (2010). Linking Job Demands and Resources to Employee Engagement and Burnout: A Theoretical Extension and Meta-Analytic Test. Journal of Applied Psychology, 95(5), 834-848. https://doi.org/10.1037/a0019364

Creary, S. J., \& Gordon, J. R. (2016). Role Conflict, Role Overload, and Role Strain. Encyclopedia of Family Studies, 1-6. https://doi.org/10.1002/9781119085621.wbefs012

Czaplewski, A. J., Ferguson, J., \& Milliman, J. (2003). Workplace Spirituality and Employee Work Attitudes: An Exploratory Empirical Assessment. Journal of Organizational Change Management. https://doi.org/10.1108/09534810310484172

Daniels, K., Beesley, N., Wimalasiri, V., \& Cheyne, A. (2013). Problem Solving and Well-Being: Exploring the Instrumental Role of Job Control and Social Support. Journal of Management, 39(4), 1016-1043. https://doi.org/10.1177/0149206311430262

Davis, T. L., Kerr, B. A., \& Kurpius, S. E. R. (2003). Meaning, Purpose, and Religiosity in At-Risk Youth: The Relationship Between Anxiety and Spirituality. 31(4), 356-365.

Duchon, D., \& Plowman, D. A. (2005). Nurturing The Spirit at Work: Impact on Work Unit Performance. Leadership Quarterly, 16(5), 807-833. https://doi.org/10.1016/j.leaqua.2005.07.008

Duxbury, L. E., Higgins, C. A., \& Network, C. P. R. N. W. (2001). Work-life balance in the new millennium: where are we? where do we need to go? /:cby Linda Duxbury, Chris Higgins. CPRN Discussion Paper, (6), 80.

Fourie, M. (2014). Spirituality in the workplace: An introductory overview. In Die Skriflig/In Luce Verbi, 48(1), 1-8. https://doi.org/10.4102/ids.v48i1.1769

Fried, Y., Grant, A. M., Levi, A. S., Hadani, M., \& Slowik, L. H. (2007). Job Design in Temporal Context: A Career Dynamics Perspective. Journal of Organizational Behavior. https://doi.org/10.1002/job.486

Fry, L. W. (2003). Toward A Theory Of Spiritual Leadership. Leadership Quarterly, 14(6), 693-727. https://doi.org/10.1016/j.leaqua.2003.09.001

Hair, J. F., Black, W. C., Babin, B. J., \& Anderson, R. E. (2014). Multivariate Data Analysis. Pearson Education Limited. 
Iroegbu, M. N. (2014). Impact of Role Overload on Job Performance among Construction Workers. Asian Journal of Social Sciences and Management Studies, 1(3), 83-86.

Jones, E., Chonko, L., Rangarajan, D., \& Roberts, J. (2007). The Role Of Overload on Job Attitudes, Turnover Intentions, and Salesperson Performance. Journal of Business Research, 60(7), 663671. https://doi.org/10.1016/j.jbusres.2007.02.014

Karakas, F. (2010). Spirituality and Performance in Organizations: A Literature Review. Journal of Business Ethics, 94(1), 89-106. https://doi.org/10.1007/s10551-009-0251-5

Kinjerski, V. M., \& Skrypnek, B. J. (2004). Defining Spirit at Work: Finding Common Ground. Journal of Organizational Change Management, 17(1), 26-42.

Kolodinsky, R. W., Giacalone, R. A., \& Jurkiewicz, C. L. (2008). Workplace Values and Outcomes: Exploring Personal, Organizational, and Interactive Workplace Spirituality. Journal of Business Ethics, 81(2), 465-480. https://doi.org/10.1007/s10551-007-9507-0

Krishnakumar, S., \& Neck, C. P. (2002). The "What", "Why" and "How" Of Spirituality in The Workplace. Journal of Managerial Psychology, 17(3), 153-164. https://doi.org/10.1108/02683940210423060

Leana, C. (2009). Work Process And Quality Of Care In Early Childhood Education: The Role Of Job Crafting University Of Pittsburgh. Academy of Management Journal, 52(6), 1169-1192.

LePine, J. A., Podsakoff, N. P., \& LePine, M. A. (2005). A Meta-analytic Test of The Challenge Stressor-hindrance Stressor Framework: An Explanation for Inconsistent Relationships among Stressors and Performance. Academy of Management Journal, 48(5), 764-775. https://doi.org/10.5465/AMJ.2005.18803921

Lyons, P. (2008). The Crafting Of Jobs and Individual Differences. Journal of Business and Psychology. https://doi.org/10.1007/s10869-008-9080-2

Malik, M. I., Sajjad, M., Hyder, S., Ahmad, M. S., Ahmed, J., \& Hussain, S. (2013). Role Overload : A Cause Of Diminishing Employee Retention and Productivity. Middle-East Journal of Scientific Research, 18(11), 1573-1577. https://doi.org/10.5829/idosi.mejsr.2013.18.11.12457

Malik, M. I., \& Usman, A. (2011). Role overload, job satisfaction and their effect on layoff survivor s job retention and productivity. Interdisciplinary Journal of Contemporary Research in Business.

Marques, J., Dhiman, S., \& King, R. (2015). Spirituality in the Workplace: Developing an Integral Model and A Spirituality in the Workplace: Developing an Integral Model and A Comprehensive Definition. (January).

Martinez, F. M. R., \& Solem, L. A. A. (2019). How do Different Types of Job Crafting Relate to Job Performance? Examining the Role of Occupational Self- Efficacy, Intrinsic Motivation, and Role Overload. BI Norwegian Business School - campus Oslo.

Mazloum, A., Kumashiro, M., Izumi, H., \& Higuchi, Y. (2008). Quantitative Overload: A Source of Stress in Data-Entry VDT Work Induced by Time Pressure and Work Difficulty. Industrial Health, 46, 269-280.

Mitroff, I. I., \& Denton, E. A. (1999). A Study of Spirituality in The Workplace. Sloan Management Review, 40(4), 83-92.

Moon, T. W., Youn, N., Hur, W. M., \& Kim, K. M. (2018). Does Employees' Spirituality Enhance Job Performance? The Mediating Roles of Intrinsic Motivation and Job Crafting. Current Psychology, 1-17. https://doi.org/10.1007/s12144-018-9864-0

Neck, C. P., \& Milliman, J. F. (1994). Thought Self-leadership: Finding Spiritual Fulfillment in Organizational Life. Journal of Managerial Psychology, 9(6), 9-16.

Olivia, F., Ardian, A., \& Mutaminah. (2014). The Role of Workplace Spirituality and Employee Engagement to Enhance Satisfaction and Performance. International Journal of Organizational Innovation (Online), 7(1), 15-35. https://doi.org/10.1016/j.intman.2012.10.002

Pawar, B. S. (2009). Some Of The Recent Organizational Behavior Concepts as Precursors to Workplace Spirituality. Journal of Business Ethics, 88(2), 245-261. https://doi.org/10.1007/s10551-008-9961-3

Petrou, P., Demerouti, E., Peeters, M. C. W., Schaufeli, W. B., \& Hetland, J. (2012). Crafting a Job on A Daily Basis: Contextual Correlates and The Link to Work Engagement. Journal of Organizational Behavior. https://doi.org/10.1002/job.1783

Pienaar, J., Mostert, K., \& Sieberhagen, C. F. (2007). Investigating Turnover Intentions by Role 
Overload, Job Satisfaction and Social Support Moderation. Journal of Industrial Psychology, 33(2), 62-67. https://doi.org/10.4102/sajip.v33i2.378

Podsakoff, N. P., Lepine, J. A., \& Lepine, M. A. (2007). Differential Challenge Stressor-hindrance Stressor Relationships with Job Sttitudes, Turnover Intentions, Turnover, and Withdrawal Behavior: A Meta-analysis. Journal of Applied Psychology, 92(2), 438-454. https://doi.org/10.1037/0021-9010.92.2.438

Saks, A. M. (2011). Workplace Spirituality and Employee Engagement. Journal of Management, Spirituality and Religion, pp. 317-340. https://doi.org/10.1080/14766086.2011.630170

Sartori, R., Costantini, A., Ceschi, A., \& Scalco, A. (2017). Not Only Correlations: A Different Approach for Investigating The Relationship Between The Big Five Personality Traits and Job Performance Based On Workers and Employees' Perception. Quality and Quantity, 51(6), 25072519. https://doi.org/10.1007/s11135-016-0406-2

Slemp, G. R., \& Vella-Brodrick, D. A. (2013). The Job Crafting Questionnaire: A New Scale to Measure The Extent to Which Employees Engage in Job Crafting. International Journal of WellBeing, 3(2), 126-146. https://doi.org/10.5502/ijw.v3i2.1

Solberg, E., \& Wong, S. I. (2016). Crafting One's Job to Take Charge of role overload: When proactivity requires adaptivity across levels. Leadership Quarterly, 27(5), 713-725. https://doi.org/10.1016/j.leaqua.2016.03.001

Suprasto, H. B., Ariyanto, D., Jati, I. K., Luh, N., Widhiyani, S., \& Suryanawa, I. K. (2017). Ability of Religiosity and Emotional Intelligence to Moderate the Effect of Role Conflict, Role Ambiguity, Role Overload, and Job Insecurity on Burnout of Tax Consultants in Bali Province. 8(18), 7-15.

Tims, M., Bakker, A. B., \& Derks, D. (2012). Development and validation of the job crafting scale. Journal of Vocational Behavior. https://doi.org/10.1016/j.jvb.2011.05.009

Triplett, R., Mullings, J. L., \& Scarborough, K. E. (1996). Work-Related Stress And Coping Among Correctional Officers : Implications From Organizational Literature. Journal of Criminal Justice, 24(4), 291-308.

Wang, G., Liu, X., \& Liu, Y. (2018). Role Overload, Knowledge Acquisition and Job Satisfaction: An Ambidexterity Perspective on Boundary-spanning Activities of IT Employees. The International Journal of Human Resource Management, 1-30.

Widodo. (2014). Metodologi Penelitian Manajemen. Semarang: Unissula Press.

Wrzesniewski, A., \& Dutton, J. E. (2001). Crafting a Job: Revisioning Employees As Active Crafters of Their Work. Academyof Management Review, 26, 179-201. https://doi.org/10.5465/amr.2001.4378011 